\title{
Different polymicrogyria patterns and associated anomalies in childhood: MRI findings
}

\section{Çocukluk çağında farklı polimikroji paternleri ve eşlik eden anomaliler: MRG bulguları}

\author{
Nisa Bașpmar ${ }^{1}$, Mehmet Atalar², Büllent Yıldız² İsmaill Șallk²
}

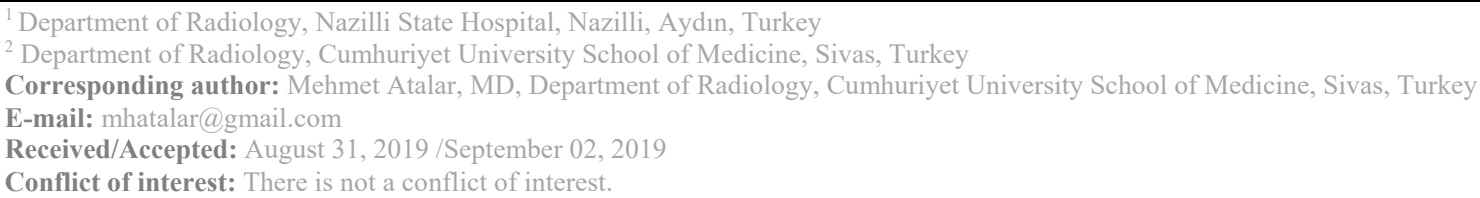

\section{SUMMARY}

Polymicrogyria is a developmental anomaly which has been diagnosed in recent years due to improvements in neuroimaging methods. It may present with very different clinical findings. It can be seen in many different patterns. It can be found with different nervous system anomalies. In this article, different polymicrogyria patterns and associated anomalies detected in childhood are presented with MRI findings.

Keywords: Magnetic resonance imaging, polymicrogyria, cerebrum

\author{
Nisa Başpınar \\ (D) Mehmet Atalar \\ (D) Bülent Yıldız \\ (D) İsmail Şalk \\ ORCID IDs of the authors: \\ N.B. 0000-0003-4240-6001 \\ M.A.0000-0003-3076-8072 \\ B.Y. 0000-0003-3836-3184 \\ İ.Ş. $0000-0002-5156-6923$
}

\section{ÖZET}

Polimikrogiri son yıllarda nörogörüntüleme yöntemlerindeki gelişmelere bağlı olarak tanısı artan bir gelişimsel anomalidir. Çok farklı kilinik bulgular ile ortaya çıkabilir. Çok farklı paternlerde görülebilir. Değişik sinir sitemi anomalileri ile birlikte bulunabilir. Bu yazıda, çocukluk çağında saptanan farklı polimikrogiri paternleri ve eşlik eden anomaliler, MRG bulguları ile sunulmaktadır.

Anahtarsözcükler: Beyin, manyetik rezonans görüntüleme, polimikrogiri

\section{INTRODUCTION}

Polymicrogyria (PMG) is a developmental cortical malformation characterized by an extremely small and markedly curvature shallow sulcus that leads to an irregular appearance in the cortical surface and the cortex and the grey-white matter junction ${ }^{1}$. PMG is believed to occur after developmental disorders or damage occurred between 17 and 26 weeks intrauterine. This period includes the end of neuronal migration and the early period of cortical organization. Bilateral PMG may be with various syndromes. Recently, the relationship between Xq28 and 16q12.2q21 gene loci of bilateral PMG has been revealed ${ }^{2}$. PMG can appear in different patterns. It may be with many CNS anomalies. Neuroradiological examination methods are important in diagnosis ${ }^{3-6}$. In this study, we present different PMG patterns and other associated anomalies detected during MRI in childhood.

\section{MATERIAL AND METHODS}

Polymicrogyria diagnosis of cases were determined by MRI, and the patient records and PACS images were retrospectively evaluated. Patients with low-quality MR images such as MRIs with motion artifacts were excluded. MR imaging was performed on two different 1.5 Tesla MRI 
devices (Magnetom Aera, Siemens, Erlangen, Germany, and Excelart, Toshiba, Tokyo, Japan) in all patients. Based on the MRI characteristics, 23 patients who were diagnosed with PMG were evaluated on $\mathrm{T} 1$ and $\mathrm{T} 2$ weighted images using the thickness of the polymicrogyric cortex-signal intensity, status of the underlying white matter and other anomalies associated with PMG. MR images were also examined concerning the location of PMG, whether unilateral or bilateral PMG, and symmetry of PMG. PMG patterns were classified as type 1 and 2 according to the cortex thickness and the underlying white matter. Type 1 pattern; small, thin and corrugated cortex $(3-5 \mathrm{~mm})$ in normal thickness. Type 2 pattern; thick cortex (6$10 \mathrm{~mm}$ ) with irregular cortex white matter junction.

Measurements of the cortical thickness were made on the PACS workstation for images that has been magnified. The thickness was the distance from the outermost gray matter to the innermost gray matter, measured perpendicular to the cortex at the thickest part of a typical region of PMG.

\section{RESULTS}

The study included 23 cases. Of the 23 cases, 10 were female $(43,5 \%)$ and 13 were male $(56,5 \%)$. The mean age of the patients was $6,5 \pm 5,3$ years (age range; 2 months - 16 years). Clinical findings of the patients ranged from partial seizures to mental motor retardation. The most common clinical finding was generalized seizure $(n=10)$. Four patients had no accompanying clinical findings. The mean age of the female cases was 8,9 $\pm 5,0$ years. The mean age of the male cases was $4,8 \pm 4,9$ years. When the distribution of PMG pattern was evaluated, there were 5 cases $(21,7 \%)$ with type 1 pattern and $18(78,3 \%)$ cases with type 2 pattern (Table 1 ).

Table 1: Distrubition of polymicrogyria patterns.

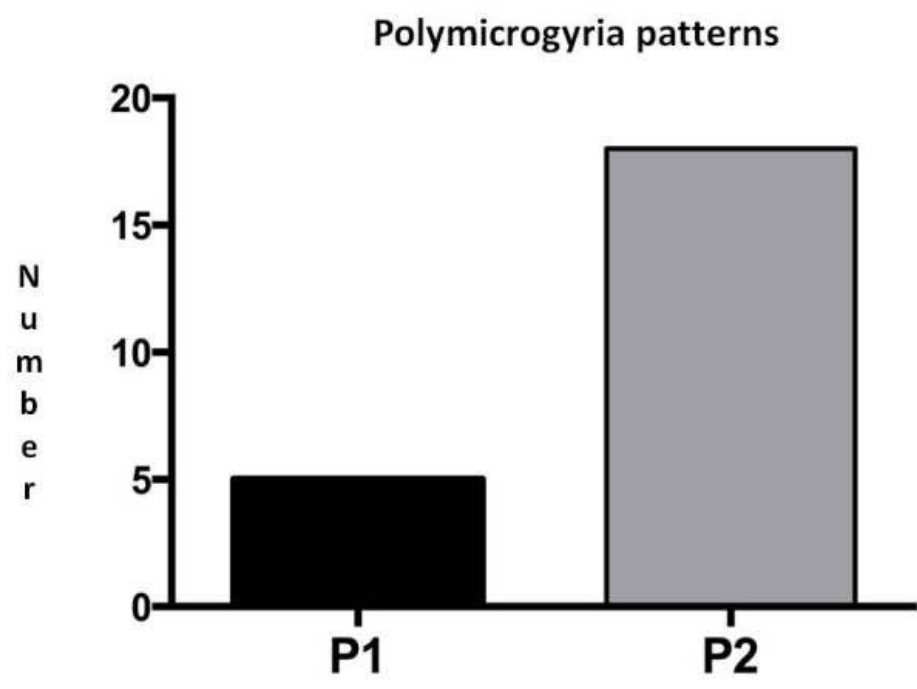

When the distribution of laterality was evaluated: 7 patients were located $(30,5 \%)$ in the left $(4$ hemispheric, 1 frontotemporal, 2 frontoparietal.); 5 patients $(21,7 \%)$ were located right; 5 hemispheric. Eleven patients $(47,8 \%)$ were bilateral (1 hemispheric, 1 frontotemporal, 3 perisylvian, 2 temporal, 3 perisylvian + occipitoparietaln (Figure 1), 1 perisylvian + frontoparietal) (Table 2). Eighteen of the 23 cases have associated anomalies. These anomalies are lissencephaly $(\mathrm{n}=1)$, Schizencephaly $(\mathrm{n}=3)$, microcephaly $(\mathrm{n}=1)$, Aicardi syndrome $(\mathrm{n}=1)$ (Figure 2), bilateral temporal cysts $(\mathrm{n}=2)$, periventricular high T2 signal $(\mathrm{n}=3)$, vanishing white matter disease $(\mathrm{n}=1)$ (Figure 3), right lateral ventricle dilatation $(n=1)$, right cerebral hemiatrophy $(n=5)$, left cerebral hemiatrophy $(\mathrm{n}=1)$, right subependymal heterotopia $(\mathrm{n}=1)$, bilateral subependymal heterotopia $(\mathrm{n}=1)$, cavum septum pellucidum et vergae $(n=1)$, periventricular leukomalacia $(n=1)$, corpus callosum agenesis $(\mathrm{n}=2)$, thick corpus callosum $(n=1)$, focal cortical dysplasia $(n=1)$, right optic atropy $(\mathrm{n}=1)$, and $\mathrm{T} 2$ high signal at subcortical white matter $(\mathrm{n}=1)$. Demographic, clinical and MRI findings of patients are briefly summarized in Table 3. 
Table 2: Distrubition of polymicrogyria localization and laterality

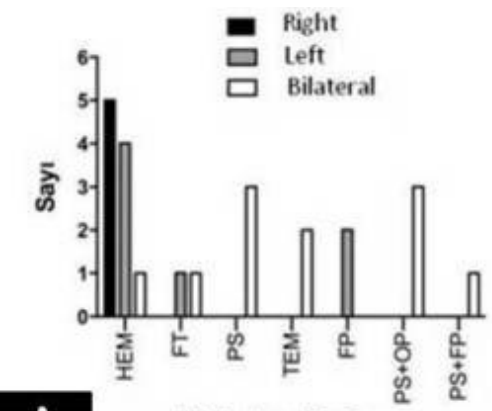

A PMG Localization

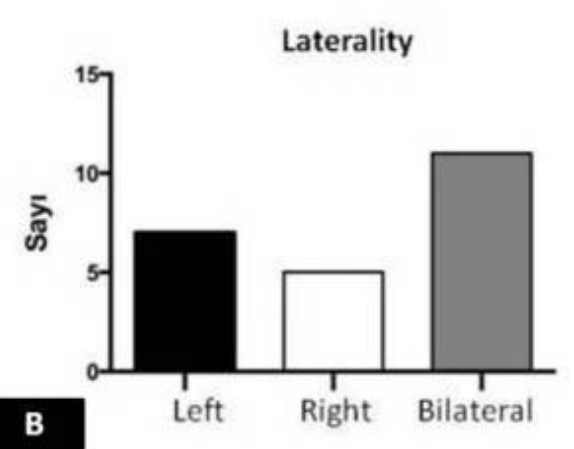

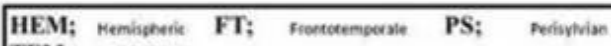

TEM: Temperzie

FP: Hortoparietale PS+OP:

PS+FP; Neribytuians tion

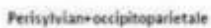

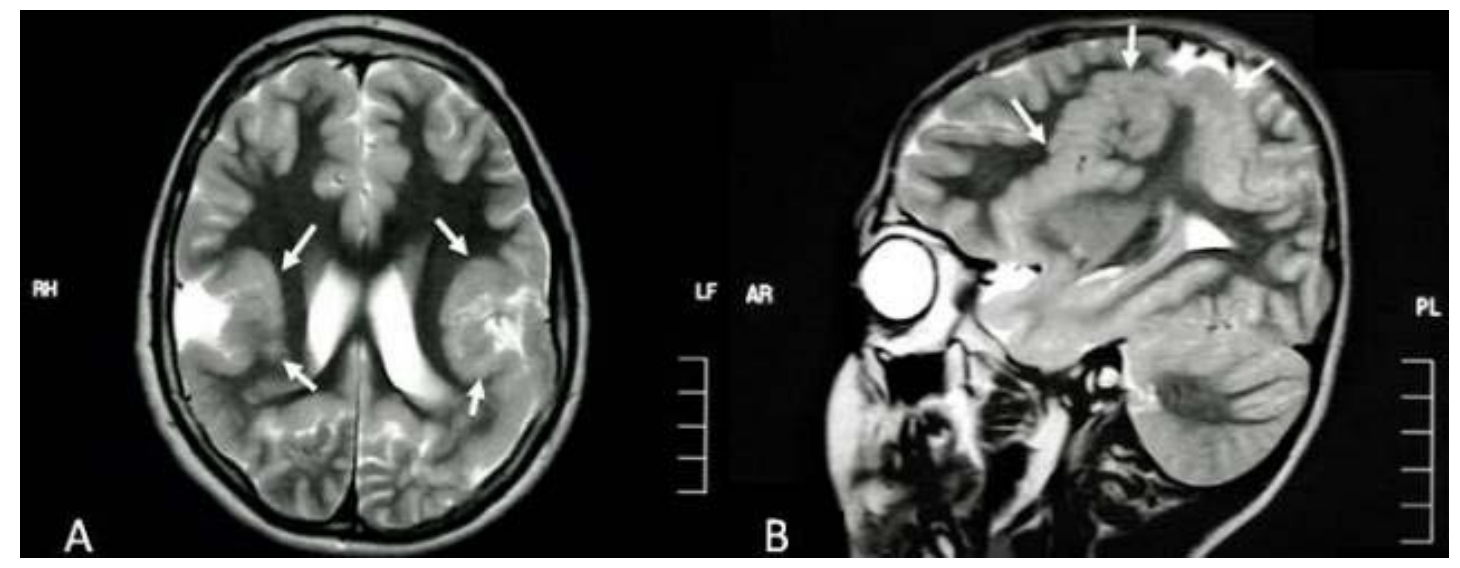

Figure 1: Twelve-year-old boy. Axial (A) and sagittal (B) T2 weighted MR images show type 2 pattern polymicrogyria in the bilateral perisylvian and occipito-parietal regions (arrows).

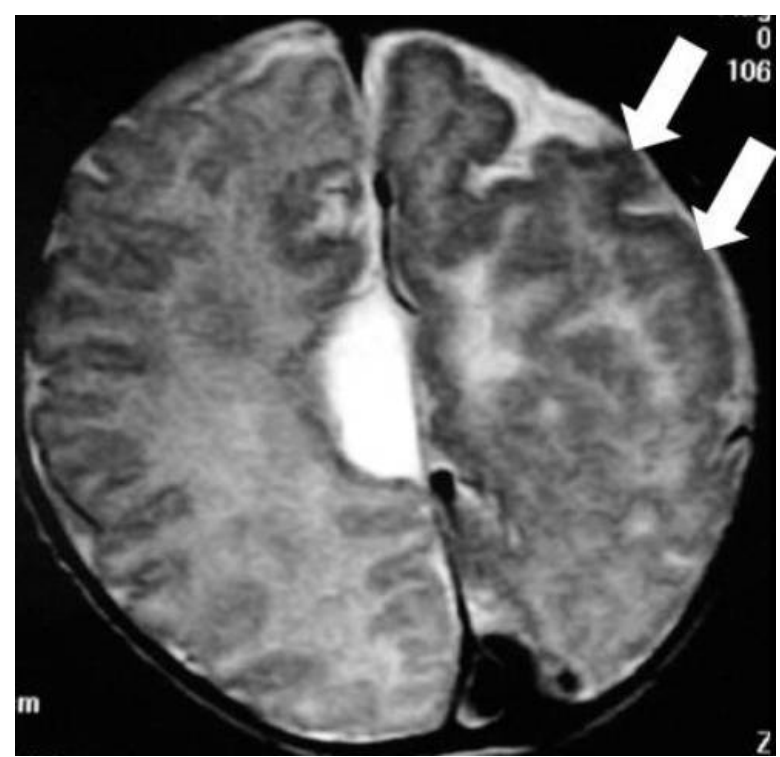

Figure 2: 2-month-old male with Aicardi syndrome. On axial T2 weighted MR image, the left frontotemporal cortex has a type 1 pattern polymicrogyria (arrows). 
Table 3. Summary of the demographic, clinical and MRI findings of patients

\begin{tabular}{|c|c|c|c|c|c|}
\hline Age/Sex & Localization & $\begin{array}{c}\text { T2W pattern } \\
\text { type }\end{array}$ & Laterality & $\begin{array}{l}\text { Associated } \\
\text { anomalies }\end{array}$ & Basic clinical findings \\
\hline $2 \mathrm{~m}, \mathrm{M}$ & Left hemispheric & 1 & Unilateral & $\begin{array}{l}\text { Lissencephaly, } \\
\text { microcephaly, } \\
\text { Schizencephaly } \\
\end{array}$ & Partial seizure \\
\hline $2 \mathrm{~m}, \mathrm{M}$ & Frontotemporal & 1 & Unilateral & Aicardi syndrome & Infantile spasms, MMR \\
\hline $3 \mathrm{~m}, \mathrm{M}$ & Perisylvian & 2 & Bilateral & - & Generalized seizure \\
\hline $10 \mathrm{~m}, \mathrm{M}$ & Left hemispheric & 1 & Unilateral & - & - \\
\hline $11 \mathrm{~m}, \mathrm{M}$ & Temporal & 1 & Bilateral & $\begin{array}{c}\text { Bilateral temporal } \\
\text { cysts, T2W PV } \\
\text { hyperintensities }\end{array}$ & Generalized seizure, MMR \\
\hline $2 \mathrm{y}, \mathrm{F}$ & Temporal & 1 & Bilateral & $\begin{array}{c}\text { Bilateral temporal } \\
\text { cysts, T2W PV } \\
\text { hyperintensities }\end{array}$ & Generalized seizure, MMR \\
\hline $3 y, F$ & Left hemispheric & 2 & Unilateral & $\begin{array}{l}\text { Vanishing white } \\
\text { matter disease }\end{array}$ & Generalized seizure, spasticity \\
\hline $3 y, M$ & Right hemispheric & 2 & Unilateral & $\begin{array}{l}\text { Right lateral } \\
\text { ventricule dilatation, } \\
\text { right cerebral } \\
\text { hemiatrophy }\end{array}$ & Partial seizure \\
\hline $3 y, M$ & Right hemispheric & 2 & Unilateral & $\begin{array}{c}\text { Right cerebral } \\
\text { hemiatrophy }\end{array}$ & - \\
\hline $4 y, M$ & Right hemispheric & 2 & Unilateral & $\begin{array}{l}\text { Right subependymal } \\
\text { heterotopia, right } \\
\text { cerebral hemiatrophy }\end{array}$ & Generalized seizure, MMR \\
\hline $4 y, F$ & Left hemispheric & 2 & Unilateral & $\begin{array}{l}\text { Cavum septum } \\
\text { pellusidum et } \\
\text { vergae, left right } \\
\text { cerebral hemiatrophy }\end{array}$ & MMR \\
\hline $5 y, M$ & Perisylvian & 2 & Bilateral & $\begin{array}{c}\text { Periventricular } \\
\text { leukomalacia, right } \\
\text { optic atrophy }\end{array}$ & Generalized seizure \\
\hline $7 y, F$ & $\begin{array}{c}\text { Perisylvian, } \\
\text { occipitoparietal }\end{array}$ & 2 & Bilateral & Schizencephaly & MMR \\
\hline $8 \mathrm{y}, \mathrm{M}$ & $\begin{array}{l}\text { Perisylvian, } \\
\text { occipitoparietal }\end{array}$ & 2 & Bilateral & $\begin{array}{c}\text { Thick corpus } \\
\text { callosum, PV } \\
\text { hyperintensities }\end{array}$ & MMR, partial seizure \\
\hline $8 \mathrm{y}, \mathrm{F}$ & Perisylvian, frontoparietal & 2 & Bilateral & Schizencephaly & MMR \\
\hline $9 y, F$ & Right hemispheric & 2 & Unilateral & $\begin{array}{l}\text { Right cerebral } \\
\text { hemiatrophy }\end{array}$ & Generalized seizure \\
\hline $11 \mathrm{y}, \mathrm{M}$ & Left frontoparietal & 2 & Unilateral & $\begin{array}{c}\text { Focal cortical } \\
\text { dysplasia }\end{array}$ & Generalized seizure \\
\hline $11 \mathrm{y}, \mathrm{F}$ & Hemispheric & 2 & Bilateral & $\begin{array}{l}\text { CC agenesis, } \\
\text { bilateral } \\
\text { subependymal } \\
\text { heterotopia }\end{array}$ & MMR, seizure \\
\hline $12 \mathrm{y}, \mathrm{M}$ & $\begin{array}{c}\text { Perisylvian, } \\
\text { occipitoparietal }\end{array}$ & 2 & Bilateral & - & Generalized seizure \\
\hline $14 \mathrm{y}, \mathrm{F}$ & Frontotemporal & 2 & Bilateral & $\begin{array}{c}\text { CC agenesis, } \\
\text { subcortical white } \\
\text { matter } \\
\text { hyperintensities }\end{array}$ & MMR \\
\hline $14 \mathrm{y}, \mathrm{M}$ & Right hemispheric & 2 & Unilateral & $\begin{array}{c}\text { Right cerebral } \\
\text { hemiatrophy }\end{array}$ & - \\
\hline $15 \mathrm{y}, \mathrm{F}$ & Left frontoparietal & 2 & Unilateral & - & - \\
\hline $16 y, F$ & Perisylvian & 2 & Bilateral & - & Generalized seizure \\
\hline
\end{tabular}

Abbrevations: m; month, y; year, T2W; T2 weighted, CC; corpus callosum, PV; periventricular, MMR; Mental motor retardation. 


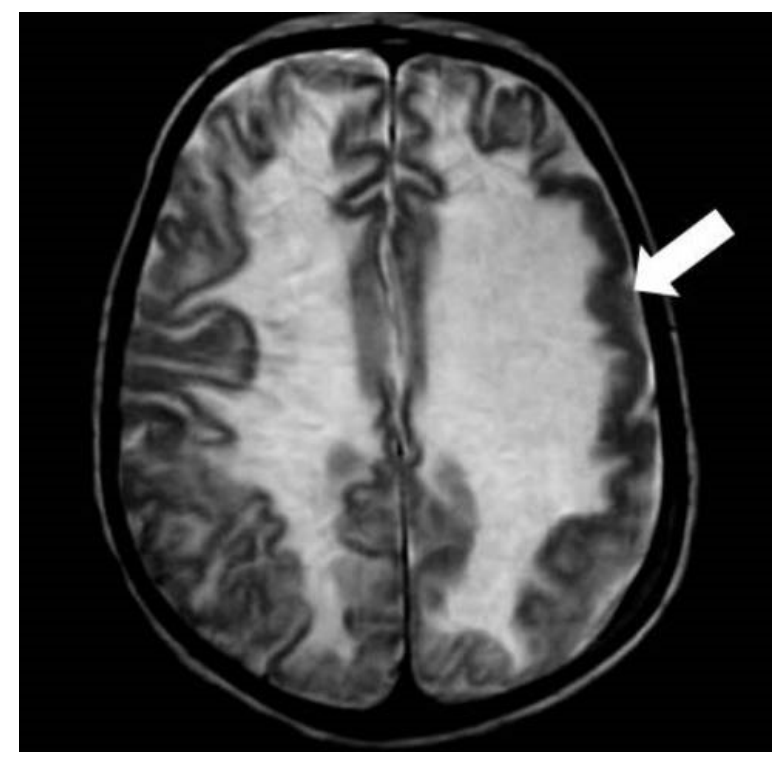

Figure 3: 3-year-old female with vanishing white matter disease. Axial T2 weighted MR image shows a type 2 pattern polymicrogyria in left cerebral hemisphere (arrow).

\section{DISCUSSION}

Polymicrogyria is one of the most common malformations of cortical development referring to pathological findings including abnormal stratification and overlapping of the cortex. In this anomaly, where the neuronal cortex can reach the cortex but the six layer normal cortex structure is disturbed due to the effect on the organization phase, it is seen that the cortex is composed of many shallow indentations ${ }^{3-7}$. PMG can be seen in all lobes. PMG most often holds the sylvian fissure and posterior portion ${ }^{8-11}$.

There are many morphological types of PMG. The appearance and localization patterns of PMG differ in T2W images. PMG can be unilateral or bilateral, symmetric or asymmetric, focal, multifocal or topographically diffuse. The preferred region is the perisylvian region 1, 3, 6, 8. Barkovich classified PMGs as coarse focal coarse - fine - localized and sawtooth according to gyral pattern ${ }^{3}$. Most of the PMGs we detected in this study were unilateral, and were most located in the perisylvian region in accordance with the current literature.

Polymicrogyria can be isolated or with different morphological or genetic malformations. The most common anomalies associated with PMG are corpus callosum dysgenesis / agenesis / hypogenesis, cerebellar hypoplasia and gray matter heterotopia ${ }^{9}$. In addition to these anomalies, the type of perisylvian may be associated with chromosomal deletion and duplication anomalies such as DiGeorge syndrome ${ }^{6,7}$. Bilateral PMG is the dominant type in patients with congenital CMV infections, Aicardi syndrome, Walker-Warburg syndrome, Ito's hypomelanosis and Schizencephaly ${ }^{1}$. In our study, different structural and congenital anomalies were accompanied in PMG patients. These anomalies were lissencephaly, Schizencephaly, microcephaly, Aicardi syndrome, bilateral temporal cysts, periventricular high T2 signal intensity, vanishing white matter disease, right lateral ventricule dilatation, right cerebral hemiatrophy, left cerebral hemiatrophy, right subependymal heterotopia, bilateral subependymal heterotopia, cavum septum pellucidum et vergae, periventricular leukomalacia, corpus callosum agenesis, thick corpus callosum, focal cortical dysplasia, right optic atropy, high signal at subcortical white matter. We found other brain anomalies in association with PMG in 78,2 \% of our patients. This rate was consistent with a recent study by Jansen et al. ${ }^{10}$ in which they stated that PMG is almost always associated with other brain malformations.

In our study, two different cortical patterns were found especially in the $\mathrm{T} 2 \mathrm{~W}$ series of patients with PMG. Type 1 pattern was common in patients aged between 2 months and 2 years. Type 2 pattern was a common in patients over 2 years old. Our results were similar to those of Takanashi and Barkovich 12.

Recent studies have demonstrated that myelination of the subcortical-intracortical fibers in PMG may alter cortical appearance in $\mathrm{T} 2 \mathrm{~W}$ images. Microscopically, two types of PMG were identified, four-layer and non-layered PMG. The 
four-layer PMG consists of a few layers of cells, a poor middle layer and a molecular layer separated by myelinated fibers and two layers of neurons. Non-layer PMG consists of a molecular layer, and a layer of non-laminar organization neurons and myelinated fibers. The appearance of polymicrogyria varies with the brain myelination 12. It has been suggested that this changing appearance is due to partial myelinization of a group of subcortical white matter pathways. As these fibers myelinated the appearance of the cortex varies from a large small gyrii containing to thin cortical layer to a thick cortex containing slightly corrugated inner surface ${ }^{10-13}$.

In rough pattern (pattern 2), we observed the depth of cortical microondulations more clearly than in fine pattern (pattern 1). However, we think that this difference in morphology may not be explained only by myelination related phenomenon.

The cortex had different thicknesses on $\mathrm{T} 1$ and $\mathrm{T} 2$ weighted images in 5 patients ranging in age from 2 months to 2 years. If myelinization of the surrounding fibers is due to the change in cortical appearance on T2 weighted images, we think that the change in thickness may be due to myelination.

Our study had some limitations. The first was the small number of cases. Second, this study is mainly limited by its retrospective nature. Third, there is no serial MRI of patients in terms of change from pattern 1 to pattern 2. Another limitation is the absence of histopathological correlation in our patients.

In conclusion, we found two different $\mathrm{PMG}$ patterns in this study. The two different views of the cortex (thin and thick) in the PMG probably show the same process, and the change in appearance results from the change in the apparent thickness and appearance of PMG in T2 weighted images as a result of myelination in subcortical and intracortical fibers. There is a need for further imaging studies on large series with the support of neuropathology in animal models. We hope that our study will provide awareness to start this process.

\section{REFERENCES}

1. Leventer RJ, Guerrini R, Dobyns WB. Malformations of cortical development and epilepsy. Dialogues. Clin Neurosci. 2008; 10: 4762.

2. Golden JA, Harding BN. Cortical malformations: unfolding polymicrogyria. Nat Rev Neurol. 2010; 6: 471-72.
3. Barkovich AJ, Gressens P, Evrard P. Formation, maturation, and disorders of brain neocortex. AJNR Am J Neuroradiol 1992; 13: 423-46.

4. Evrard P, de Saint-Georges P, Kadhim HJ, Gadisseux JF. Pathology of prenatal encephalopathies. In: French J (ed) Child neurology and developmental disabilities. Paul H. Brookes, Baltimore, 1989, pp 153-76

5. Englund C, Fink A, Lau C et al. Pax6, Tbr2, and Tbr1 are expressed sequentially by radial glia, intermediate progenitor cells, and postmitotic neurons in developing neocortex. J Neurosci 2005; 25: $247-51$

6. Dobyns WB, Mirzaa G, Christian SL, Petras K, Roseberry J, Clark GD, et al. Consistent chromosome abnormalities identify novel polymicrogyria loci in 1p36.3, 2p16.1-p23.1, 4q21.21-q22.1, 6q26-q27, and21q2. Am J Med Genet A 2008; 146: 1637-54

7. Robin NH, Taylor CJ, Donald-McGinn DM, Zackai EH, Bingham P,Collins KJ, et al. Polymicrogyria and deletion 22q11.2 syndrome: window to the etiology of a common cortical malformation. Am J Med Genet. 2006; 140: 241625.

8. Barkovich AJ, Kuzniecky RI, Jackson GD, Guerrini R, Dobyns WB. Classification system for malformations of cortical development: update 2001. Neurology 2001; 57: 2168-78.

9. Öztoprak B, Atalar MH. Aberrant fissure in polymicrogyria. Cumhuriyet Medical Journal. 2016; 3: 185-194.

10. Jansen AC, Robtaille Y, Honavar M, Mullatti $\mathrm{N}$, Leventer RJ, Andermann E, Andermann F, Squier W. The histopathology of polymicrogyria: a series of 71 brain autopsy studies. Dev Med Child Neurol 2016; 58: 39-48.

11. Hayashi N, Tsutsumi Y, Barkovich AJ. Morphological features and associated anomalies of schizencephaly in the clinical population: detailed analysis of MR images. Neuroradiology 2002; 44: 418-27.

12. Guerrini R, Dravet C, Raybaud C et al. Epilepsy and focalgyral anomalies detected by MRI: electroclinico-morphological correlations and follow-up. Dev Med Child Neurol 1992; 34: 70618.

13. Takanashi J, Barkovich AJ. The changing MR imaging apearance of Polimicrogyria: A consequence of myelination. AJNR Am J Neuroradiology 2003; 4: 788-93. 